Halina Parafianowicz

\title{
THE U.S. IN THE AGE OF TERRORISM: SECURITY, JUSTICE AND CIVIL RIGHTS
}

George W. Bush entered the White House without much experience in either U.S. foreign policy or international relations. As the governor of Texas (19952001) he was considered as being the archetypical Southerner and a provincial politician. To his critics and many of his countrymen, he was an ignoramus in world affairs, with foggy ideas about international order. Ironically, from the outset of his administration, President Bush was challenged with the grave danger of terrorism involving the U.S. in international policymaking, much more so than was predicted by strategists.

September 11, 2001, after the terrible and spectacular terrorist attacks on the World Trade Center in New York and the Pentagon in Washington, D.C, became a very sad and traumatic day and not only for Americans. Four hijacked airplanes destroyed the World Trade Centre, heavily damaged the Pentagon and killed around 3000 people. On September 11(now commonly referred to as 9/11), the symbols of U.S. economic and military power were the terrorists' goals. The unprecedented character and scale of the attacks was shocking for Americans and for the whole of the civilized world. Speculation grew over the intended target of the fourth hijacked plane, which was heroically downed by its passengers in Pennsylvania. Most likely it was the White House or Capitol Hill, which together with many other governmental facilities were evacuated ${ }^{1}$. In circumstances of uncertainty and under the possibility of additional attacks, the U.S. government too immediate action to respond and plan retaliation. This tragic day, as claimed by many, changed America and Americans forever.

On the evening of September 11, in his Address to the Nation speech, President Bush condemned this cruel attack and encouraged his fellow countrymen. He said: The The pictures of airplanes flying into buildings, fires burning, huge structures collapsing, have filled us with disbelief, terrible sadness, and a quiet, unyielding

1 Rick Fawn, From Ground Zero to the War in Afghanistan, [in:] Global Responses to Terrorism. 9/11, Afghanistan and Beyond, ed. by Mary Buckley and Rick Fawn, London-New York, 2003, p. 12. 
anger. These acts of mass murder were intended to frighten our nation into chaos and retreat. But they have failed; our country is strong.

A great people has been moved to defend a great nation. Terrorist attacks can shake the foundations of our biggest buildings, but they cannot touch the foundation of America.(...) America and our friends and allies join with all those who want peace and security in the world, and we stand together to win the war against terrorism. (...). This is a day when all Americans from every walk of life unite in our resolve for justice and peace. America has stood down enemies before, and we will do so this time. None of us will ever forget this day. Yet, we go forward to defend freedom and all that is good and just in our world ${ }^{2}$.

Europe identified with the U.S. after 9/11 in symbolic declaration "we are all Americans!" sprang from the front pages of the press. Immediate international Sympathy for Americans and solidarity was tremendous and visible around the world. In Poland the mass media covered this tragic event in detail, sharing sorrow and ourning with Americans and their anxiety for the security ${ }^{3}$.

On September 11, 2001, America and Americans were confronted by a traumatic event that effected people individually and collectively. Their personal sense of security was shattered, and America's territorial integrity was violated to an even greater degree than at Pearl Harbor. At Pearl Harbor, soldiers protecting the state were killed; at the World Trade Center, civilians, who were supposed to be protected by the state, were victims ${ }^{4}$.

Americans responded to the terrorist attacks with a remarkable and visible patriotism and bitter anger. The hijackings and subsequent killings were crimes under America's law that the U.S. had jurisdiction to prosecute. President Bush immediately declared a strong response to this criminal act and grave danger for the security of America and its citizens.

The cruel terrorist attacks on the World Trade Center and Pentagon emotionally devastated Americans, the more so since America was attacked within its own boundaries, in the heart of the country. According to many witnesses and scholars this was an unprecedented horrible day. America had just been dealt its biggest blow since Pearl Harbor. Half of lower Manhattan lay buried in rubble, dust and smoke. The Pentagon, the symbol of US invincibility, was smoldering. Citizens

2 "We Will Prevail". President George W. Bush on War, Terrorism, and Freedom. Selected and Edited by National Review, New York 2003, p. 2.

3 In TV, radio and every-day press there was a lot of sympathy and condolences addressed to the friendly American nation.

4 George Soros, The Age of Fallibility. The Consequences of the War on Terror, London, 2006, p. 101. 
were terrified; the country was clearly under attack. And enemy agents could still be somewhere within its borders ${ }^{5}$.

The Bush response to the 9/11 attacks was to declare that the United States was at war. On 12th September the president labeled the attacks "acts of war" and firmly declared to fight those terrorists responsible and their supporters. In the following days Americans, shocked and emotionally devastated, shared the official views and approach towards terrorists. Immediately after the attacks on New York and Washington, American public opinion polls had found majorities (ranging from 66 to 81 percent) of Americans accepting a formal declaration of war against terrorism. Many Americans believed 9/11 to be the prelude to further serious terrorists' attacks. On September 14, 2001 both houses of Congress passed a resolution giving the president right: to use all necessary and appropriate force against those nations, organizations, or persons he determines planned, authorized, committed, or aided the terrorist attacks that occurred on September 11, 2001, or harbored such organizations or persons, in order to prevent any future acts of international terrorist against the United States by such nations, organizations, or persons ${ }^{6}$.

In a radio address on September 15, 2001, Bush declared "the war against terrorism". He repeated his thanks to brave and understanding Americans and assured that the U.S. government took a broad and sustained campaign to secure our country and eradicate that evil terrorism. (...) Great tragedy has come to us, and we are meeting it with the best that is in our country, with courage and concern for others. Because this is America. This is who we are. This is what our enemies hate and have attacked. And this is why we will prevail ${ }^{7}$.

On September 17, 2001, the president issued a top-secret directive to George Tenet, director of the CIA, ordering the agency "to hunt, capture, imprison, and interrogate suspects around the world". So, under this order, the CIA began to function as "global military police, throwing hundreds of suspects into secret jails" . Soon Osama bin Laden was pronounced the chief suspect. Later, in a video recording shown on television, he took credit for the 9/11 attacks and called on Muslims to fight a jihad against America and its allies.

On September 20, at the joint session of Congress, President Bush demanded the surrender of Al Qaeda leaders and terrorists from the Taliban leadership in Afghanistan and a few days later, on September 24, he issued an Executive Order

5 Mattew Brzezinski, Fortress America: On the Frontlines of Homeland Security, and Inside Look at the Coming Surveillance State, New York, 2004, p. 86.

6 Timothy J. Lynch, Robert S. Singh, After Bush. The Case for Continuity in American Foreign Policy, Cambridge, 2008 , p. 74. The resolution was accepted by unanimous voting in Senate (98:0) and the House of Representatives (420:1).

7 "We Will Prevail"..., p. 8-9.

8 Tim Weiner, Legacy of Ashes. The History of the CIA, New York 2008, p. 555-556. 
to disrupt and freeze terrorist finances. In the meantime, although unsuccessful, Pakistani President Musharraf tried to convince the Taliban to surrender bin Laden and to eek a diplomatic solution with the Americans. The U.S. administration, supported by Great Britain and other Western countries, as well as Russia, was preparing for a war, which - as many predicted - was inevitable?

In the meantime the American administration declared as its main goal to fight and eliminate of global terrorism, focused much of attention on its leaders. The FBI published the names and photos of the twenty-two "most wanted terrorists". In the atmosphere of fear and alerts of imminent further attacks forecast by the FBI and Attorney General John Ashcroft, government took very strong anti-terrorists approach.

In the later judgment of many observers and scholars, September 11 was that catastrophic failure which might almost have been predictable. They argued that the possibility of danger of terrorists' attacks was visible, as George Tenet, CIA director in 1997-2004, had predicted three years before. In the consequence, as critically and bitterly argued by one author: It was systematic failure of American government - the White House, the National Security Council, the FBI, the Federal Aviation Administration, the Immigration and Naturalization Service, the congressional intelligence committees. It was a failure of policy and diplomacy. It was a failure of the reporters who covered the government to understand and convey its disarray to their readers. But above all it was a failure to know the enemy ${ }^{10}$. What's more, there are some serious arguments that prior to the 9/11 attacks, the Bush administration did not implement carefully and seriously a homeland security policy. It is hard to expect that Tenet was objective in his later judgement about Bush and U.S. security policy, but similar opinions were and are shared by other officials and scholars.

So, as we see, the U.S. declared "war on terrorism" immediately after the attacks and in an atmosphere of fear of further possible danger The "crusade" against terrorism declared by President Bush on September 16, 2001, was supported by many politicians and congressmen ${ }^{11}$. Americans responded to the attacks with mixed feelings - a bitter anger and fear. Common support for the government's activities became very visible and loud. Actually, such phraseology is quite typical in American policymaking. The U.S. government often declared "war" or "crusade" against sometimes "nebulous enemies" at home - poverty, drugs, crime or abroad communism, evil empire or tyranny etc.

President Bush proclaimed "the war against terrorism" and was searching for the strong and substantial support of Americans as well as foreigners. The attacks

R. Fawn, op. cit., pp. 13-15.

T. Weiner, op. cit., p. 555.

www.yale.edu/lawweb/avalon/sep_11/president_015.htm; www.yale.edu/lawweb/avalon/sept_11/house_proc_091401.htm 
could have happened anywhere else, so all free nations were invited to fight against terrorism together, side by side. So, as some politicians admitted, the war on Islamic terrorism ensured that the United States was committed to a long fight against jihadism in many places, not limited only to the Middle East. While many commentators focused attention on strategic and military aspects, scholarly critics of the military intervention in Afghanistan (and later in Iraq) also focused on the growing power of the president and executive office. The more so, they saw that the announced preventive war against Iraq was a "a war of choice" rather than necessity ${ }^{12}$.

After 9/11 Washington began "buzzing" about the possibility of Saddam Hussein providing weapons of mass destruction (WMD) to Al Qaeda or other terrorist groups and networks for use against America and/or its allies. The danger of further terrorist attack (proved in some way by a series of anthrax attacks beginning on September 18) was unpredictable, yet quite possible, the more so the media and public opinion were deluged with speculations about such potentiality ${ }^{13}$.

In the following weeks the administration had been preparing the military attack against the Taliban in Afghanistan with the substantial support of foreign countries. The U.S. and its allies - as argued by its politicians and later also by many scholars - were justified in resorting to force in Afghanistan under the principle of selfdefense or preventive war. Other nations enlisted in that struggle; NATO sent troops to Afghanistan and most countries exchanged intelligence and cooperated through police and the courts in searching for and bringing to justice terrorists and those suspected of having links with terrorist organizations. The fight with the Taliban became a sort of prelude to the next step in the war against terrorism - the preparation to attack Saddam Hussein and Iraq. The U.S. declared war against the Taliban on the premise that the regime supported the activities of Al-Qaeda, so the main goal of this mission in Afghanistan ("Operation Infinite Justice", "Operation Enduring Freedom") was to root out the Al-Qaeda terrorists and destroy their training camps ${ }^{14}$.

On October 7, 2001 the United States together with its allies began the attack against Al-Qaeda and the Taliban in Afghanistan. Initially the war produced some visible results; some Al-Qaeda leaders were captured or killed and some of those providing aid to it were punished So America and its allies rapidly accomplished the main objectives of being in Afghanistan, but they didn't capture bin Laden, and many others terrorist warriors escaped to Pakistan and other neighboring countries.

12 Louis Fischer, The Way We Go to War: The Iraq Resolution, [in:] Considering the Bush Presidency, Oxford, 2004, pp. 107-124.

13 More on the role of media: Elinor Kelley Grusin, Sandra H. Utt, eds., Media in an American Crisis: Studies of September 11, 2001, Lanham, c2005; Anthony R. Dimaggio, Mass Media, Mass Propaganda: Examining American News in the "War on Terror", Lanham, c2008. 
According to scholars: In Afghanistan, U.S. forces failed to eliminate the leadership of Al-Qaeda. Equally, although they toppled the Taliban regime that had ruled most of that country, they failed to eliminate the Taliban movement which soon began to claw its way back. Indeed as a brief campaign, the Afghan War became a protracted one. Nearly seven years after it began, there is still no end in sight. If anything, America's adversaries are gaining strength. The outcome remains much in doubt ${ }^{15}$. Perhaps from today's perspective this critical opinion has justification, the more so we know that the fight is not yet finished. But we should remember that in October 2001 there was another perspective and both American and European public opinions were very supportive to the idea of fighting against terrorists in Afghanistan.

On October 25, 2001, the President signed two directives implementing the fight against terrorism and others improving U.S. national security. In coming weeks the administration undertook some action to modernize and improve the efficiency of units and agendas promoting security for citizens and the state. First of all, in October 2001, President Bush strengthened the status of homeland security through establishment of the Office of Homeland Security (OHS), Later raised to a departmental position. Governor Tom Ridge, as its director, was charged with coordinating and implementing homeland security policy. In coming months he became quite successful in his activities ${ }^{16}$.

In following weeks the administration developed a variety of strategies in the campaign against Al-Qaeda, focusing on the wide spectrum of domestic and international resources, assets and tactics. The most important tool to implement the strategy and policy of fighting terrorism was the congressional decision, known as the USA Patriot Act, signed into law by President George W. Bush on October 26, $2001^{17}$.

The Attorney General, John Ashcroft, became extremely active and innovative in the war against terrorism, which later resulted in bitter criticism from many of his fellow countrymen. First of all he ordered the surveillance of all individuals and organizations suspected of being involved in terrorist activities. Many people of Arabic roots came under surveillance, some were arrested and interrogated (without legal consent) and some were deported ${ }^{18}$. Up to the beginning of November 2001

15 Andrew J. Bacevich, The Limits of Power. The End of American Exceptionalism, New York, 2009, p. 125.

16 Robert Singh, Superpower Response, [in:] Global Responses to Terrorism. 9/11, Afghanistan and Beyond, ed. By Mary Buckley and Rick Fawn, London-New York, 2003, p. 58.

17 The acronym stands for Uniting and Strengthening America by Providing Appropriate Tools Required to Intercept and Obstruct Terrorism Act of 2001 (USA PATRIOT). More on the Patriot Act, Stewart A. Baker, John Kavanagh, eds., Patriot Debates: Experts Debate the USA Patriot Act, Chicago, 2005; Howard Ball, ed., The USA Patriot Act of 2001: Balancing Civil Liberties and National Security: A Reference Handbook, Santa Barbara, 2004; Debra A. Miller, The Patriot Act, Detroit, 2007.

18 John Ashcroft in book (Never Again. Securing America and Restoring Justice, New York, 2006) presented his own judgment of governmental activities and his role in fighting terrorism. He was quite satisfied and proud of the results of this policy. 
more than 1140 people were arrested under suspicion of terrorism. The important and timely problem in the war against terrorism was how to do it effectively and adequately within American values. Later it became a more and more serious problem for the Bush administration, mostly because of the cruel, inhuman and degrading treatment of detainees ${ }^{19}$.

George Bush put in place a number of new federal agencies and institutions to fight terrorism at home. The Department of Homeland Security (DHS) ${ }^{20}$ established in 2002 in the Department of Defense, was his substantial achievement in counter terrorism strategy. The national security of the U.S. has been subject to formal control since 1947, but homeland security has not. There was not a single governmental agency which could focus its attention on home security. Instead many dispersed organizations were responsible for conducting homeland security ${ }^{21}$.

For the United States, the war on terror became and still is a fundamentally strategic goal, which involves a series of campaigns to secure the geo-strategic situation, retardation of terrorism and building the prospects of democracy and stabilization. Officially declared by Bush, the Global War on Terrorism (GWOT), it became a fundamental part of U.S. foreign policy in the following years. Politicians of all political persuasions declared their support for "the global war", which was likely to continue for decades if not generations. The Bush Doctrine became the fundamental initiative for U.S. national security ${ }^{22}$. The National Security Strategy declared that the aim of the war is to defeat global terrorism. The first application of the Bush Doctrine took place in Afghanistan; the second occurred in Iraq.

The Patriot Act became the most important legal base in the National Strategy for Combating Terrorism (NSCT), which was officially announced in February 2003 , just before the invasion of Iraq. What is interesting, is that around 70 percent of American approved of this invasion. Certainly, in the following months some of them, learning more about the reality of it, changed theirs minds, but most of them believed (or wanted to believe?) that there was a real danger to American and world safety from Saddam Hussein. Moreover, most of them believed that he was the organizer of the 9/11 attacks in New York and Washington ${ }^{23}$.

\footnotetext{
19 Phillip H. Gordon, Winning the Right War. The Path to Security for America and the World, New York, 2007, pp. 17-22.

20 Tom Lansford, "Homeland Security from Clinton to Bush: An Assessment", "White House Studies", 3, 4, 2003.

21 T. Lynch, R. Singh, op. cit., pp. 115-116.

22 www.whitehouse.gov/nsc/nss.pdf

23 Morris Berman, Dark Ages America. The Final Phase of Empire, New York, 2006; Al. Gore, The Assault on Reason, London, 2007, p. 3. Gore, heavily critical about conducting policy by the Republican administration and the president wrote: In fact, not long after the attacks of 9/11 President Bush made a decision to start mentioning Osama bin Laden and Saddam Hussein in the same breath, in a cynical mantra designed to fuse them together as ones in the public's mind. He repeatedly used his device in a highly disciplined manner to create a false impression in the minds of the American people that Saddam Hussein was responsible for 9/11 (p. 108).
} 
The Bush administration's policy, accepted largely by U.S. public opinion, as shown constantly in polls, sought also congressional approval for its fight against global terrorism. On October 10, 2002, the Senate (77:23) and the House of Representatives (296:133) voted in favor of the Iraq resolution. It is worth mentioning that at this time Congress was not so united on this issue. Republican senators voted "yes" (48; one was in opposition), but Democrats were divided (29 "yes" and 21 "no"). In the House of Representatives, 215 Republicans supported the resolution, while 6 voted against. The majority of Democrats (126) voted against, while 81 of them voted in favor of it. The resolution authorized the president: 'to use the Armed Forces of the U.S. as he determines to be necessary and appropriate to (1) defend the security of the U.S. against the continuing threat posed by Iraq and (2) enforce all relevant Security Council Resolutions regarding Iraq ${ }^{24}$.

In the State of the Union Speech on January 28, 2003, the president talked about biological weapons possessed by Saddam who can use them at any time against America $^{25}$. All of this was terrifying but none of it, as was discovered later, was true. But the U.S. government used all possible arguments to find any reasons (or rather excuses) for its decision about the war against Iraq. Secretary of State Colin Powell went to the United Nations to get understanding and support for the American policymaking. On February 5, 2003, he talked about biological weapons in Iraq and assured the audience that there were "facts and conclusions" based on "solid intelligence". Yet his arguments were rather doubtful for the audience felt quite hesitant about $\mathrm{it}^{26}$. On March 18, 2003, Bush formally declared war on Iraq, which started two days later without the support of the United Nations. One of Bush's critics wrote that: the administration made ostentatious claims about weapons of mass destruction that turned out to be false, alleged links between Iraq and Al-Qaeda that did not exist, berated allies for refusing to back an invasion they argued would be unwise, and carried out the invasion without a viable plan for what to do if it produced chaos, civil war, and terrorism, which it $\operatorname{did}^{27}$. Unlike in the case of the war in Afghanistan, this time round America failed to get the unanimous weight of public opinion behind it. This decision, already questioned by some, seriously damaged America's credibility and moral authority.Six weeks after the invasion, on May 1, 2003, President Bush landed on the "USS Abraham Lincoln" and proclaimed "Mission Accomplished". He publicly declared that major military operations have ended. Yet, in the following months and years Americans have been losing in Iraq even more soldiers than during the invasion ${ }^{28}$. The killing of Americans became

http:whitehouse.gov/news/releases/2003/01/20030128-19.html

See, Russ Hoyle, Going to War: How Misinformation, Disinformation, and Arrogance Led America into Iraq, New York, 2008.

P.H. Gordon, op. cit., p. 18.

A.J. Bacevich, op. cit., p. 203. The author dedicated book to his son, who was killed in action in Iraq on May 13, 2007. 
an increasingly more serious argument for their fellow countrymen against U.S. involvement in the region. If and how successful the U.S. has been in Iraq, remains a highly debated topic, the more so now that Americans know much more about the hidden facts of "the Bush war".

When the war was officially declared won on May 1, 2003, the subsequent occupation proved that many difficult problems existed in Iraq. The rogue states Syria and Iran - supported the rebels in many ways and both armed and financed them. The war on terrorism had not ended, but rather - as many predicted - it was growing.

Richard A. Clarke, a former anti-terrorism coordinator has argued that the war on terrorism is being lost, showing the atrocities, which have doubled since $9 / 11^{29}$.

By the end of 2007, nearly 4000 Americans had been killed in Iraq. The major criticism went to the occupation and misconduct. The Iraq war divided and polarized America and pushed president and Congress against each other after the mid-term elections in 2006. According to some critics much of the "Vietnam Syndrome" was being regenerated as the "Iraq Syndrome"

The United States had to pay a huge amount of money for its security and the international security as well. There is a systematic rise in the costs of many activities linked with it and so-called security alerts. Nobel Prize winner, Joseph E. Stiglitz, with anxiety and uncovered criticism wrote about the enormous cost of "Iraq's disturbance". According to Stiglitz, up to 2008 America had paid more for the Iraq war than for Vietnam and twice that of Korea ${ }^{31}$.

Under the concept of preemptive war, the U.S. had, before 9/11, prepared for war with the Taliban in Afghanistan. Similarly, the invasion of Iraq formed part of U.S. preemptive strategy in the fight against terrorism. Bush and his close associates (Dick Cheney, Condoleezza Rice, Donald Rumsfeld - to name only a few albeit the most influential) rolled on the war machine, even though from the outset the motives were questioned by many Americans as well as by many of America's foreign allies ${ }^{32}$. Yet many other Americans believed the information about Weapons

29 Richard A. Clarke, Against All Enemies. Inside America's War on Terror, New York, 2004. He was also bitterly critical about President Bush and his staff ignoring in Summer, 2001 the alerts on danger of terrorism for America and after $9 / 11$ misusing by them this tragic experience. And later he wrote sarcastically: In the end, what was unique about George Bush's reaction to terrorism was his selection as an object lesson for potential state sponsors of terrorism not a country that had been engaging in anti-U.S. terrorism but one that had not been, Iraq. It is hard to imagine another President making that choice (p. 244).

30 A.J. Bacevich, op. cit., pp. 125-126. In Iraq he saw "a reprise of Vietnam, although in some respects at least on blessedly smaller scale".

31 Joseph E. Stiglitz, Linda Bilmes, The Three Trillion Dollar War: The True Cost of Iraq Conflict, New York, 2008.

32 Ahmed Nafeez is extremely critical about American policy before and after the attacks (The War on Freedom: How and Why America Was Attacked September11, 2001, London, 2002); also Emmanuel Todd, Schyłek imperium. Rozważania o rozkładzie systemu amerykańskiego, Warszawa 2003; Bob Woodward, Stan zakłamania, Warszawa, 2007; State of Denial, New York: Simon \& Schuster, 2006. 
of Mass Destruction (WMD) that were being produced or likely to be produced by Iraq. So the fight against terrorism was in part implemented by the plan to relieve the world of a potentially grave danger - the possession of WMD by Iraq. Another goal was to overthrow Iraq's cruel and bloody dictator and to build democracy and freedom for the Iraqi people. Americans, with their idea of mission, were gained over by such a promising moral aspect of U.S. intervention in Iraq. Perhaps this explains unquestionably the high level of approval and support afforded to President Bush's policy by the majority of Americans, not only at the beginning of the war but also later.

Historically the United States had enjoyed a special providence, based mostly on exceptionalism in terms of geography, ideas and policy of continental expansion. Its policy has been shaped by some threats, real or potential, and Americans have experienced some hard times and insecurity; the Alamo, fort Sumter, Pearl Harbor and recently September 11, 2001, to name but a few. America was more secure than other countries and U.S. foreign activities have been expansive and moralistic, the more so for its geograhic situation. But moral aspirations are rather dubious in implementing foreign policy. Certainly, in such unpredictable and dangerous circumstances Americans have reasons to demand improvements in the nation's security whether at significant cost or otherwise. But they want to know the truth, the reality and the possible price they have to pay.

For many Americans the question of whether the Bush administration cynically exploited a climate of fear to advance presidential power, became more than an academic issue. They gradually criticized the abuse of power by Bush and his close associates for violation of the Constitution and building the "imperial presidency". As a consequence of the war in Iraq, according to many anxious countrymen, the rise of presidential power and strengthening role of the military was clearly visible. In the following years many Americans became concerned over the potential failure of obedience to the Constitution and the abuse of civil right ${ }^{33} \mathrm{~s}$.

One critic of Bush and his policy was Al Gore. In his book "The Assault on Reason" he attacked the president and his close associates for the falsification and manipulation of Americans and Congress after 9/11 using governmen officials and the media. He argued against the Bush Doctrine, which used the extraordinary conditions to expand the prerogatives of the executive branch and for building a national security system based on a garrison state fed by fear and obsession ${ }^{34}$.

33 There is huge amount of literature on the subject: Nancy Chang, Silencing of Political Dissent: How PostSeptember 11 Anti Terrorism Measures Threaten Our Liberties, New York, 2002; Donald J. Musch, Balancing Civil Rights and Security: American Judicial Responses Since 9/11, Dobbs Ferry, 2003; Elaine Casel, The War on Civil Liberties: How Bush and Ashcroft Have Dismantled the Bill of Rights, Chicago, 2004; Fagan Ginger Ann, ed., Challenging U.S. Human Rights Violations Since 9/11, Amherst, 2005. 
In President Bush's policy and U.S. involvement in a long and devastating war in Iraq, Gore saw a real danger for the American political system and its credibility. He was extremely critical of the Republican establishment and abuse of power by the president and executive branch, which were using the real, as well as the imaginary danger of terrorism to America. Under Bush's guidance the U.S. did not follow the Geneva Conventions, which in consequence led to creating (with the semi-approval of officials) the inhuman prison systems in Gauntánamo and Abu Ghraib ${ }^{35}$.

Many Americans, mostly leftists, were against Bush's handling of civil liberties in the war on terror and persistent U.S. violations of international law - from the Geneva Conventions to the UN Charter. Participating in this public debate on U.S. involvement in Iraq and "the war on terrorism" were many intellectuals, lawyers, historians, journalists and the like, which included Noam Chomsky ${ }^{36}$ - celebrated linguist, Benjamin R. Barber ${ }^{37}$ - renowned political scientist, Tony Judt ${ }^{38}$ - author, editor and frequent contributor to "The New York Review of Books", and many others.Benjamin R. Barber, author of several articles and books on jihad, Islam and terrorism, explains that American insecurity and fear are the base for the sacrifice of its freedom. He claimed that John Ashcroft took advantage of the situation and built in the "fear estate" a feeling of security for Americans. In consequence the Prosecutor General himself became the real danger to American democracy and civil rights. Terrorism then, as he argued, a real danger to fundamental freedom is successfully spreading its mission and seeding its fear ${ }^{39}$.

Bush critics raised a growing list of charges such as, warrant less wiretapping, monitoring of financial transactions by the National Security Agency (NSA), surveillance, prisoner abuse, interrogation, military tribunals, presidential primacy, etc. Civil libertarians objected to many aspects of post-9/11 polities as "cynical overreaction" to the security threats that threatened liberties, such as privacy protection, freedom of speech and press etc. They argued that counter- terrorism must accommodate itself to the law and constitutional liberties, the more so they claimed that the erosion of wartime liberties will remain after the war and its emergency. They criticized the presidential power and "imperial presidency", very dangerous for the American Constitution and political system itself ${ }^{40}$.

35 A. Gore, op. cit., p. 60-65

36 Noam Chomsky, Interventions, San Francisco, 2007. This is a selection from his writings from newspapers on Bush and his policy. See also in Polish, Polityka, anarchizm, lingwistyka. Terror, wojna i globalny kapitalizm, Poznań 2007. His critical book on U.S. policy (Hegemony or Survival, New York, 2004), got a lot of publicity and careful attention not only in America. There is also Polish edition - Hegemonia albo przetrwanie: Amerykańskie dążenie do globalnej dominacji, Warszawa, 2005.

37 Benjamin R. Barber, Jihad vs. McWorld, New York, 1996; Fear's Empire: War, Terrorism, and Democracy, New York, 2003.

38 Tony Judt, Denis Lacorne, eds., With Us or Against Us: Studies in Global Anti-Americanism, New York 2005.

39 Benjamin R. Barber, Imperium strachu. Wojna, terroryzm i demokracja, Warszawa, 2005, pp. 81-82.

40 Susan J. Tabrizi, At What Price? Security, Civil Rights, and Public Opinion in the Age of Terrorism, [in:], David B. Cohen, John W. Wells, eds., American National Security and Civil Liberties in An Era of Terrorism, New York, 
Some authors argue that the war against terrorism was approved by most Americans and that civil rights essentially were unhampered, which is confirmed by polling data ${ }^{41}$. Perhaps the citation from George Soros explains it somewhat. The author, critical of Bush and his policy, emphasized that his administration fostered and magnified the fear that gripped the nation and used it to further its own interests. The public lined up behind the president in the war on terror and allowed him to engage in policies that would have been impossible in normal times (...). The terrorist attack was real indeed, and it required a strong response; but the response chosen by the Bush administration carried the nation into a fantasyland created by misinterpretation of reality. What is worse, people still do not recognize the phantasmagoric element in the war on terror. I shall have a hard time getting my point across because the war on terror has been unquestioningly accepted by the public; indeed, it is seen as the natural response to the terrorist attacks of 9/11 even by those who are opposed to the Bush administration's policies ${ }^{42}$.

The neo-conservatives played a significant role in arguing for the strengthening of U.S. defense and security in the age of terror. The Bush rhetoric was a sort of ideological direction in which many Americans expected the promise for stability and order. The declared war with "Islamo-fascism" and "Axis of Evil", pronounced many times by the president, became a visible part of his "crusade" against terrorism ${ }^{43}$.

Since April 2004, when Abu Ghraib began to appear in the media, there was a new wave of strong criticism on the torture and the abuse of power by Americans. American democracy, which was and should be an example and role model for other states and nations, came under fire around the world, even in friendly nations ${ }^{44}$. The activists of Amnesty International (AI) were strongly against brutal abuses at the prisons in Guantánamo and Abu Ghraib ${ }^{45}$.

In public debate many prominent activists, journalists and writers raised again a serious problem facing America and the world, e.g. the relationship between

2004, pp. 185-197; Al Gore, op. cit., pp. 132-139,142-150.

41 www.galluppoll.com/content/default.aspx?ci=5263. In 2005, 62 percent Americans thought the Patriot Act was about right" and/or that it "does not go far enough". 34 percent believed it "goes too far".

42 G. Soros, op. cit., pp. 101-102.

43 Ira Chermus, Monsters to Destroy: The Neoconservative War on Terror and Sin, Boulder 2006, pp. 121-142, 151162.

44 Seymour M. Harsh, Chain of Command: The Road From 9/11 to Abu Ghraib, New York, 2004; Joseph Margulies, Guantánamo and the Abuse of Presidential Power, New York, 2006.

$45 \mathrm{http}: / /$ washingtonpost.com/wp-dyn/content/article/2005/05/25/AR200505525018 
security and civil liberties ${ }^{46}$. The official commission was established to explain this shameful case and involvement of American soldiers ${ }^{47}$.

In the "war against terrorism" perhaps the most active and important role was played by the Secretary of Defense, Donald Rumsfeld, "the war hawk". His strong militaristic approach after a few years of controversial war became an object of criticism even from Republicans, including some governmental officials. The growing criticism towards this very unpopular secretary, especially after the "discovery" of inhuman treatment and abuses in Abu Ghraib and Guantánamo, resulted finally in his resignation from office in the autumn of 2006. Yet he finished his job with a special official ceremony and honors ${ }^{48}$.

An important part in the public debate on the prison system, its tortures and legal Abuse, was played by lawyers ${ }^{49}$. Joseph Margulies from Northwestern University Law School in Chicago is very critical about the prison system built by Bush in 2002, which he called "the ideal interrogation chamber". This is "unaccepted in the American legal system", the more so as many of these prisoners were not guilty of any terrorist activity against the U.S. ${ }^{50}$

Some of the lawyers, such as Alan Dershowitz, a renowned academic from Harvard Law School, became a strong defender of President Bush and his policy ${ }^{51}$. Quite a similar attitude was demonstrated in his writing by Jean Bethke Elshtain from the School of Divinity at the University of Chicago, who strongly defended the Bush policy and "brutal by its nature, the war against terrorism". He emphasized that America's struggle, not appreciated enough and criticized by many, was a devoted fight for the security of America and the whole world ${ }^{52}$.

America's involvement in Iraq without legal basis and against the tradition ofa long-held commitment to international law, influenced a sharp decline of U.S. respect and credibility in the international community. There is a growing number of

46 There are interesting interviews with 25 intellectuals and public persons in Sut Jhally, Jeremy Earp, eds., Hijacking Catastrophe. 9/11, Fear and the Selling of American Empire, Northampton, 2004. Similar with the idea of interviews is the book of Polish writer, Artur Domosławski - Ameryka zbuntowana. Siedemnaście dialogów o ciemnych stronach imperium wolności, Warszawa, 2007. It's worth mentioning very interesting lawyer's book, Maureen Webb, Illusions of Security: Global Surveillance and Democracy in the Post-9/11 World, San Francisco, 2007

47 Strasser Steven, ed., The Abu Ghraib Investigations. The Official Reports of the Independent Panel and Pentagon on the Shocking Prisoner Abuse in Iraq, New York, 2004.

48 Andrew Cockburn, Rumsfeld. An American Disaster, London, 2007.

49 See: Richard M. Pious, The War on Terrorism and the Rule of Law, Los Angeles, c2006; James R. Silkenat, Mark R. Shulman, eds., The Imperial Presidency and the Consequences of 9/11: Lawyers React to the Global War on Terrorism, Westport, c2007.

50 Joseph Margulies, Guantánamo and the Abuse of Presidential Power, New York, 2006.

51 Should the Ticking Bomb Terrorist Be Tortured? A Case Study in how a Democracy Should Make Tragic Choices (pp. 132-163).

52 Jean Bethke Elshtain, Just War Against Terror. The Burden of American Power in a Violent World, New York, 2003. 
books on anti-Americanism as an international political phenomenon ${ }^{53}$, which badly astonishes and worries Americans. After Bush, the decline of America's role and its position in the world order became visible. It's very likely that U.S. power is and will be accepted, mostly not for its moralistic approach but for its constant utility in an unstable and dangerous world. At least there are such expectations.

As many authors suggest, the U.S. cannot operate successfully outside of or against the international legal framework. Yet, according to Robert Keegan, who repeated it many times, security, not law, established American legitimacy' in those predominantly Western European nations that sought it ${ }^{54}$. Truly speaking, in U.S. history we can hardly find a president who has put the requirements of international law above the demands of national security.

The intervention in Afghanistan and invasion of Iraq, even for many friendly Muslims towards United States, became a sort of wider war against Islam, which worried many Americans. Distinguished diplomat and former Ambassador to Saudi Arabia Chas W. Freeman, on October 4, 2007, talked to the Pacific Council on International Policy and the American Academy of Diplomacy about diplomacy in the age of terror. He said: But our actions and rhetoric have served to persuade a very large majority of Muslims that we are engaged in a global assault on them and their faith. American relations with the Islamic world, especially the fifth of it that is Arab, have never been so hostile or mutually disrespectful. Our television and radio talk shows, aimed at domestic audiences, are heard abroad. In discussion among ourselves we routinely equate Islam with terrorism. This has made it even harder for Muslim friends of the United States to openly to cooperate with us in opposing the extremists who are our common enemies. ${ }^{55}$

Ambassador Freeman noted that in Bush's America there was a strong preference for solving problems by militaristic behavior rather than diplomacy, cooperation or promotion of legal norms. "Islamo-fascism" was invented and the rise of "Islamophobia" took place. This impacted heavily on the worsening image of the U.S. around the world, not only in evil states but also in friendly nations. To regain its spiritual strength and allied support, America must restore its reputation "as the speaker for the world's conscience, not its most powerful abuser". He declared that the urgent task for Americans will be to devise a coherent strategy to deal with the very real danger posed by terrorists with global reach and their ideological base among the world's Muslims. The United States needs a strategy that integrates intelligence,

53 Andrew Ross, Kristin Ross, eds., Anti-Americanism, New York, 2004; Brendon O'Connor, Martin Griffiths, eds., The Rise of Anti-Americanism, London-New York, 2006; Peter J. Katzenstein, Robert O. Keohane, eds., Anti- Americanism in World Politics, New York, 2006; Richard Higgott, Ivona Malbasics, eds., The Political Consequences of Anti-Americanism, Milton Park, 2008; Giacomo Chiozza, Anti-Americanism and the American World Order, Baltimore c2009.

54 Robert Kagan, “A Matter of Record”, “Foreign Affairs” 84, 1, 2005, p. 170-173; T. Lynch, R. Singh, op. cit., p. 41.

55 http://www.unc.edu/depts/diplomat/item/2007/1012/free/freeman_diplomacy.html 
diplomacy, economic measures, and information policy with law enforcement and military power. We need a grand strategy that unites us with the enemies of our enemies and regains the collaboration and support of now alienated allies and friends. (...) Rediscovering diplomacy, professionalizing it, developing doctrine to coordinate other instruments of statecraft with it, and training to get better at it are essential components of the grand strategy for combating Islamic terrorism that we require ${ }^{56}$. Restoring peace and security in a disturbed world is the main goal and a real challenge for the United States and its allies. Many American experts, including officials, emphasize the need and necessity to learn more about Islam and restoration of respectful relationships with the Muslim world.

In coming to a close, I would like for a moment to go back in chronology. On May 20, 2000, in a commencement address to the U.S. Coast Guard Academy in New London, Connecticut, Secretary of State Madeleine Albright shared some thoughts and remarks on the general problem of security for the U.S. and the world. She emphasized that Americans must be better prepared and also protect themselves from the unexpected because of our military strength, potential enemies may try to attack us by unconventional means such as sabotage and terror. They may seek to disrupt our government, sow fear within our communities, inhibit our travel, and make it harder for us to keep or deploy our troops overseas ${ }^{57}$.

Madeleine Albright stressed that in so dangerous a world Americans must act together with others, since no nation can guarantee its security alone. In responding to this grave possible danger, the U.S. must be prepared for the fight any time. Concluding she said: Our purpose is to create an ironclad web of arrangements, laws, inspectors, police, and military power that will deny criminals and aggressors the space they need to operate and without which they can not survive ${ }^{58}$. It looks that there still remains a current and timely problem, and a real challenge for America, her associates and for all of us.

In the global village terrorism became the public evil number one. The terrorist attacks on the U.S. and European cities (Madrid, London) as well as many other places and countries around the world, show evidently that there are no limits and no borders for such a danger and attempts of terrorist attacks. Extremists could also try suicidal attacks on public gatherings, government buildings or airplanes, using conventional or non-conventional weapons. The more important is then a better information system and close cooperation to prevent such a potential danger and protect the security for the people. The question of how long the threat will remain -

\footnotetext{
56 http://www.unc.edu/depts/diplomat/item/2007/1012/free/freeman_diplomacy.html

57 Madeleine Albright, Focus on the Issues Building Peace and Security Around the World, Washington, United Stets Department of State, 2000, p. 44. 
and what evolving balance between liberty and public safety is prudent to meet the threat - is rather impossible to predict or estimate.

Neither George W. Bush nor the U.S. and its allies had won "the war on terror". But it is very likely that the strong American response against the grave danger had made her future more safe from such traumatic incidents as 9/11. It lies beyond measurement but fortunately it did not happen and hopefully will never happen again. 


\section{USA W DOBIE TERRORYZMU: BEZPIECZEŃSTWO, SPRAWIEDLIWOŚĆ I PRAWA OBYWATELSKIE}

Atak terrorystyczny na Stany Zjednoczone 11 września 2001 r. spowodował ogromną traumę Amerykanów, którzy odebrali to jako zamach na ich wolność i bezpieczeństwo. Ogłoszona przez prezydenta George'a W. Busha „wojna z terroryzmem" była w pełni aprobowana przez zszokowanych rodaków, a wkrótce też uzyskała duże poparcie międzynarodowe. Zarówno Kongres (Patriot Act), jak i miliony Amerykanów poparły politykę administracji republikańskiej, godząc się także - w imię bezpieczeństwa własnego i państwa - na działania ograniczające ich niezbywalne prawa i swobody obywatelskie. Jednakże wkrótce poczynania rządu, a w szczególności naruszanie praw obywatelskich (aresztowania, inwigilacja, podsłuchy etc.) i budowanie imperialnej prezydentury spotkały się ze wzrastającą krytyką Amerykanów. W Stanach Zjednoczonych podjęto rozległą publiczną dyskusję na ten temat, ogniskując uwagę na realnych i potencjalnych zagrożeniach swobód obywatelskich, wynikających z bezpardonowej walki z międzynarodowym terroryzmem. Interwencja przeciwko talibom w Afganistanie jesienią 2001, potem wojna w Iraku postawiły wiele dalszych pytań i wywołały wątpliwości odnośnie metod i celów polityki amerykańskiej. W niemałym też stopniu nadszarpnęły pozycję międzynarodową i autorytet moralny Stanów Zjednoczonych, zwłaszcza po ujawnieniu faktów o torturach i znęcaniu się nad więźniami w Guantánamo i Abu Ghraib.

Key words:

Terrorism, U.S. security, civil rights, George W. Bush, war in Iraq 